$\underline{\underline{n}}$

PRIMARY RESEARCH

\title{
A study on the design/development time of e-learning projects in New Zealand
}

\author{
Sweety Viral Naik ${ }^{1}$, Kumar Laxman ${ }^{2 *}$ \\ ${ }^{1,2}$ Faculty of Education, University of Auckland, Auckland, New Zealand
}

\section{Key Words \\ Design/development \\ E-learning projects \\ New Zealand \\ Web-survey}

Received: 14 May 2016

Accepted: 15 June 2016

Published: 27 February 2017

\begin{abstract}
This is an exploratory descriptive research study undertaken to explore "What is the time and cost to make one hour of E-learning in New Zealand?" It seeks to investigate the time and cost involved in the development of one hour of E-learning in tertiary and corporate E-learning in NZ. Also, it seeks to establish any changes occurring in training and development and to determine the dynamics influencing the strategies and policies of those responsible for employee development. The study employed a web-survey delivered through e-mail. The survey questionnaire was sent to 200 E-learning development professionals in different industries. The return rate was $32 \%$. The data were analysed using statistical analysis using pivot tables, Cronbach's alpha, correlation and descriptive statistics. The findings imply that E-learning is not just a carrier for cutting costs and diminishing the learning options but, the needs of the learners and the business must take priority and shape our thinking as we consider the investment options for using technology to create a quality learning experience.
\end{abstract}

(C)2017 The Author(s). Published by TAF Publishing.

\section{INTRODUCTION}

Dabner et al. (2010), in a Ulearn 2010 conference, emphasized the need for transformation in education to meet the needs of the industrial society, that no longer exists. As today's economy is rapidly changing, it demands employees to adapt quickly, work efficiently and creatively and to think critically in this technology-rich world. New Zealand companies are striving to provide 'anytime, 'anywhere' learning to remain competitive in the global marketplace (Daniel 1996; Katz 1999). However Crump and Andrea (2003) argue that despite the encouraging trend in E-learning, the digital divide remains in New Zealand (New Zealand Ministry of Economic Development, 2001).

Learning 'using' technologies has become a global phenomenon (Gulati, 2008). E-learning offers many advantages and hence, there is more inclination of companies and educational institutes towards adopting E-learning. The increased investment in the E-learning has brought the need to demonstrate the cost-efficiency of the investments with respect to time taken to develop the training. Bates $(2000,8)$ writes that the pressure to change training in higher education will occur because of three factors: "the need to do more with less, the changing needs of society, and the impact of new technologies on teaching, learning, and research".

\footnotetext{
${ }^{*}$ Corresponding author: Kumar Laxman

${ }^{\dagger}$ Email: k.laxman@auckland.ac.nz
} 


\section{Overview of Issues}

An executive summary by Higgins and Prebble (2008) mentions the need for chief executives of companies to ask the question "How much will it cost to resource E-learning within the organization?" Also, an E-learning developer consultant Tucker (2014) on a word press on E-learning development blog mentions, "One skill I'm constantly trying to improve is estimating how long it will take to complete a project." Further continuing she mentions, "If I don't, I either bid low and lose money or bid high and lose a project." Hence, there exists a dire necessity in E-learning development industry to quantify the time and costs involved in E-learning development. Siegel (2013) from icon logic blog writes, "One of the more common questions that I get from new E-learning developers is how much time it will take to produce published content."

\section{Purpose of Study}

The main aim of this study was to assess the average E-learning product development time and costs in a New Zealand context. The data from this study will be a useful source of reference for those who are planning to embark on E-learning projects, be they for in-house consumption or servicing external vendors/clients. Strategic decisions around E-learning are likely to be affected by unpredictable factors such as learning and development, department size, budget and learner numbers. Therefore, this study will statistically account for the impact of these random factors in evaluating E-learning development time and cost. Estimating the cost of online learning is an essential component in the decision whether moving training to an online format is appropriate for a particular training situation (Bartley and Jennifer, 2004; Tarmuchi et al., 2015; Si and Priyanwada, 2016; Nuchso et al., 2016). This study will try to address that issue by surveying commercial E-learning practitioners regarding current and typical online learning development time. The aim is to assist L \& D practitioners to estimate a budget for undertaking E-learning projects or compare their current expenditure against industry norms. This study will be significant as it is the first of its kind conducted within a New Zealand context and the findings of this study will be of valuable help to $\mathrm{L} \& \mathrm{D}$ and E-learning leaders and practitioners in the corporate industries.

\section{RESEARCH METHODOLOGY}

\section{Survey Instrument}

The survey (Appendix A) was made available through a web link: (goo.gl/HbuVZe). The questions were developed from the adaption of the items in Chapman (2010) 6 questionnaire with additional questions based on similar studies (Garg, 2010). Additions, modification, and deletions were made through collaboration with subject matter experts.

According to Dillman (2000) the survey items must be written to be respondent-friendly and to extract the desired information. He emphasizes that the survey must be simple, use a simple wording, consist of short questions, and aim for short responses. Dillman et al. (1999) also suggest that questions should draw the respondent in and motivate him or her to respond to the survey. Open-ended questions early in the survey draw the respondent in and encourage buy-in. Dillman et al. (1999) state that questions should be specific and be written with the assumption that the respondents know less about the subject than they actually may know.

Strengths of online surveys were that they are inexpensive, have a rapid turnaround for data collection, and the data entry is easy, if not automatic a few of the weaknesses were also taken into consideration such as need valid e-mail address and respondent needs access to a computer, respondent needs to be computer literate and frequently overused 
questions. Questions were designed so specific that the respondents did not have to make unnecessary calculations. The questions were developed to avoid any double standards or bias. In the survey, both open-ended and closed-ended questions were selected depending on the response expected. If standard yes or no type answers were expected, closed-ended questions were asked. For example question 10 asked, "Are the E-learning products you create, used internally by your organization's employees or external customers/clients?" For open-ended questions ordered questions and unordered questions with hybrid questions were also asked which led the survey respondent to write comments to clarify the question in detail. The survey developed for this study consisted of 17 major questions. The closed questions were designed to elicit specific answers. The open-ended questions allowed the respondents to answer a broad question about the clarification of roles or type of interactivity used in the E-learning. Some of the questions asked the respondent to select one response. Some questions provided respondents with a list of responses and requested they check all that apply. The closed questions were the demographic questions, which asked for information about the no. of hours worked, the size of the industry, the type of the industry, the institution's budget (and the proportion of the budget from state sources), the percentage out of the annual budget allocated to E-learning development, etc.

\section{Pretesting}

Litwin (1995) suggests that pretesting can help eliminate many errors, and makes the survey more reliable. Hence, before the survey was conscripted, pretesting was carried out by E-learning knowledgeable professionals to confirm that respondents produce valid responses for the survey. Pretesting by subject experts included reading the questions as intended, to highlight poorly worded questions, ensure clear instructions and the determined amount of time needed. It confirmed the following: right type of questions is asked, i.e. Open-ended vs. close-ended, number of questions asked and response options were professional. Fowler's standards for questions development were considered; they include consistent understanding and consistent administration format, to ensure that respondents knew what answer formats are acceptable and expected, answerable question so that everyone is willing to answer each question for the necessary applicability, or it can be unknown (Fowler, 2002).

\section{Data Collection}

The researchers chose to collect data electronically for reasons found in the literature on using e-mail to distribute a survey. Compared to mailed surveys, research indicates respondents are more apt to respond, respond more openly, and provide longer answers to open-ended questions when using an Internet survey (Dillman, 1998; Grover, 2003; Mehta and Eugene, 1995; Shafer and Don, 1998; Bachmann et al., 1996).

\section{RESULTS}

This section will present the key results question-wise for the survey items. They are described in the following table:

Categories of E-learning development according to learning objective, Course Type and Level of multimedia used in E-learning projects.

Of the 200 contacts for participation in the survey, 64 companies responded to the survey from all over New Zealand. 
TABLE 1. Learning objectives explained

\begin{tabular}{|c|c|c|c|c|}
\hline Learning Objective & 1- Recall of facts and information & $\begin{array}{l}2 \text { - Application of learned skills } \\
\text { (cognitive, process or procedural) }\end{array}$ & $\begin{array}{l}3 \text { - Analysis and Synthesis of skills } \\
\text { and information }\end{array}$ & 0 - Other Blended Level 1, 2 and 3 \\
\hline & $\begin{array}{l}\text { (e.g. Presentation of company } \\
\text { policies, job descriptions and } \\
\text { objectives, details of protocols, } \\
\text { strategies or processes) }\end{array}$ & $\begin{array}{l}\text { (e.g. How to use a software ap- } \\
\text { plication, repair a car engine, ap- } \\
\text { ply an outlined process, find and } \\
\text { use information to solve a prob- } \\
\text { lem scenario) }\end{array}$ & $\begin{array}{l}\text { (e.g. How to change tact in a busi- } \\
\text { ness meeting, how to be a better } \\
\text { manager, how to solve a complex } \\
\text { problem, diagnose a patient) }\end{array}$ & \\
\hline
\end{tabular}

TABLE 2. Course type explained

\begin{tabular}{|c|c|c|c|c|c|}
\hline Course Type & 1 - Presentation & & 2 - Interactive Scenarios & 3 - Games/Simulations & 0 - Other \\
\hline & $\begin{array}{l}\text { (Built using } \\
\text { SlideShark etc.) }\end{array}$ & PowerPoint, & $\begin{array}{l}\text { (Built using software such as Lec- } \\
\text { tora, Captivate, ToolBook, Train- } \\
\text { erSoft, Articulate, etc.) }\end{array}$ & $\begin{array}{l}\text { (Built using coding languages } \\
\text { such as C++, Java, HMTL5, etc.; } \\
\text { possible use of avatar characters, } \\
\text { custom interactions, etc.) }\end{array}$ & Blended Level 1, 2 and 3 \\
\hline
\end{tabular}

TABLE 5. Results of data by course type; Question 14

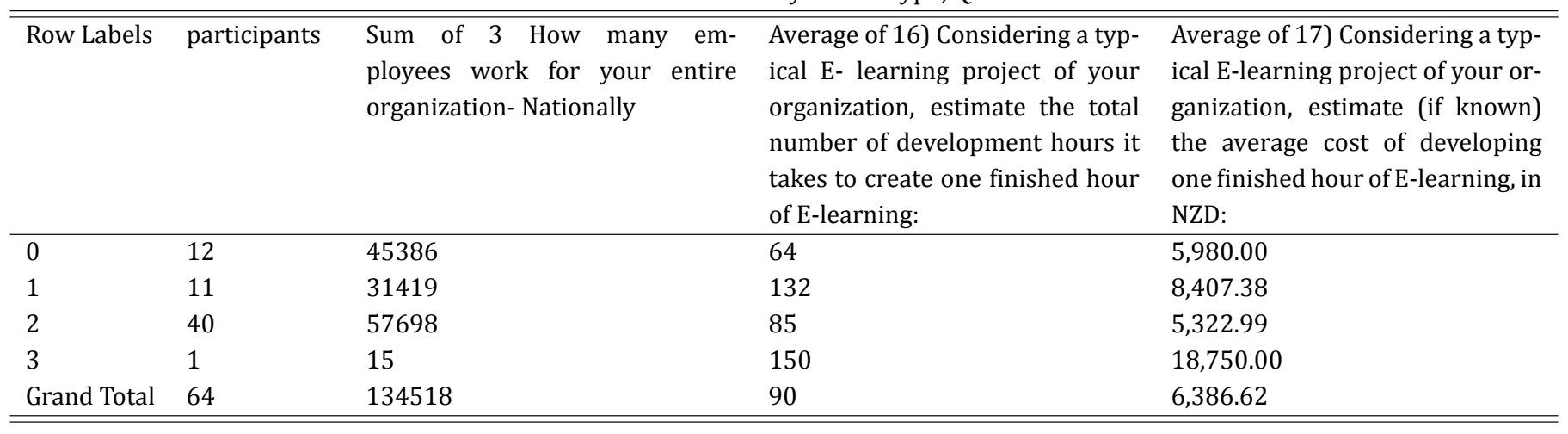
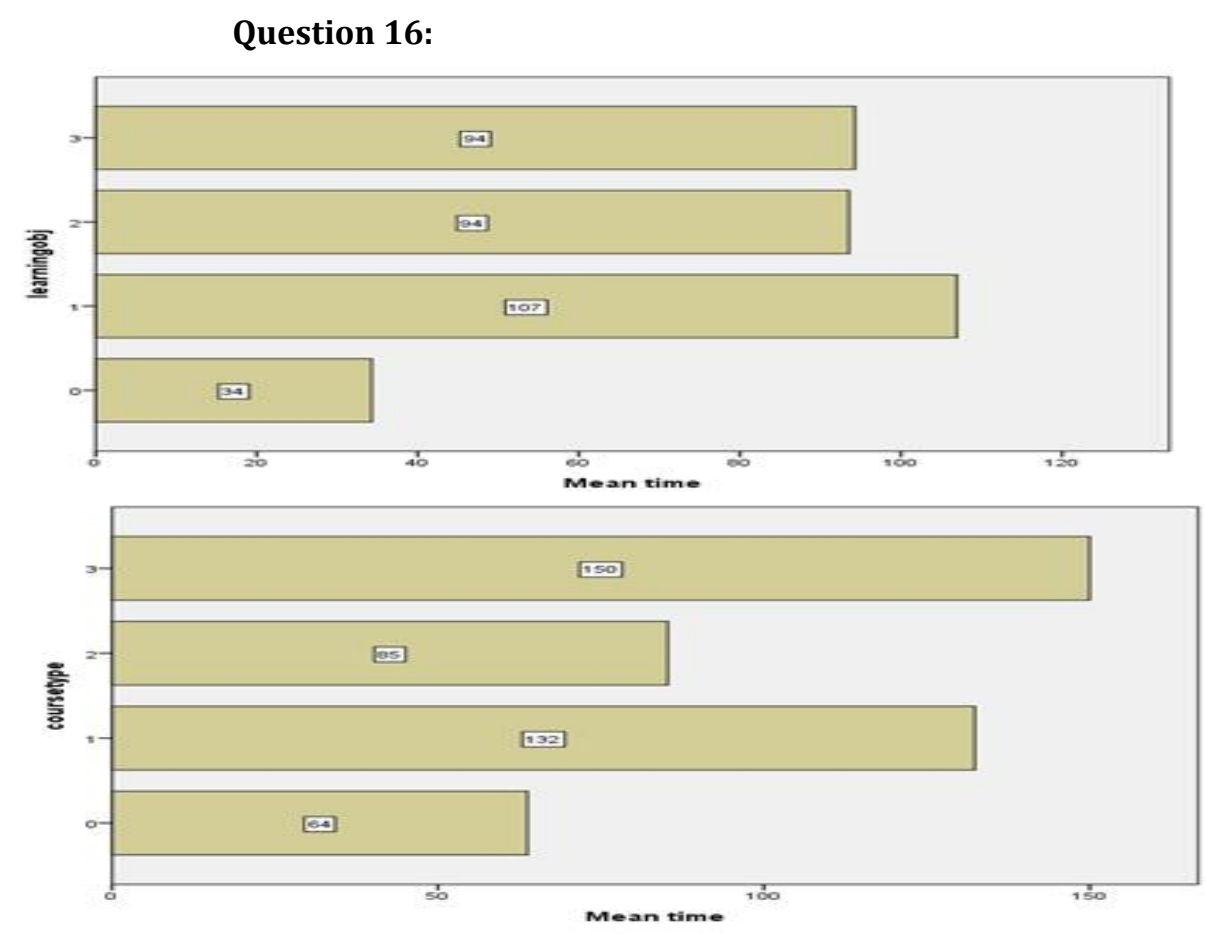

FIGURE 2 . Average development time vs. course type 
TABLE 3 . Level of multimedia explained

\begin{tabular}{|c|c|c|c|c|}
\hline Multimedia used & 1 - Level 1 (Basic) & 2 - Level 2 (Intermediate) & Level 3 (Advanced) & 0 - Other Blended Level 1, 2 and 3 \\
\hline & $\begin{array}{l}\text { Any or all of the following: text, } \\
\text { images, graphics, audio and } \\
\text { video. }\end{array}$ & $\begin{array}{l}\text { Any of Level 1, plus animations } \\
\text { such as click and reveal, hotspots, } \\
\text { drag \& drop, multiple choice. }\end{array}$ & $\begin{array}{l}\text { Complex animations and sim- } \\
\text { ulations, virtual environments, } \\
\text { multi-user/player environments, } \\
\text { high fidelity graphics, com- } \\
\text { plex multi-level, multi-variable } \\
\text { interactions. }\end{array}$ & \\
\hline & $\begin{array}{l}\text { Mostly reliant on templates for } \\
\text { layout and pages development }\end{array}$ & $\begin{array}{l}\text { If characters are used, they are } \\
\text { mostly static with speech boxes. } \\
\text { Use of templates is low or nil. }\end{array}$ & $\begin{array}{l}\text { If characters are used, then an- } \\
\text { imated characters are with live } \\
\text { movements (lip synching, head } \\
\text { and body movements, expres- } \\
\text { sions). Graphics may be created } \\
\text { in 3D }\end{array}$ & \\
\hline
\end{tabular}

TABLE 4. Results by learning objective type; Question 13

\begin{tabular}{|c|c|c|c|c|}
\hline Row Labels & Participants & $\begin{array}{l}\text { Sum of 3) How many em- } \\
\text { ployees work for your entire } \\
\text { organization- Nationally }\end{array}$ & $\begin{array}{l}\text { Average of 16) Considering a typ- } \\
\text { ical E- learning project of your } \\
\text { organization, estimate the total } \\
\text { number of development hours it } \\
\text { takes to create one finished hour } \\
\text { of E-learning: }\end{array}$ & $\begin{array}{l}\text { Average of 17) Considering a typ- } \\
\text { ical E- learning project of your } \\
\text { organization, estimate (if known) } \\
\text { the average cost of developing } \\
\text { one finished hour of E-learning, in } \\
\text { \$NZ: }\end{array}$ \\
\hline 0 & 7 & 12264 & 34 & $5,160.00$ \\
\hline 3 & 7 & 19512 & 94 & $12,142.86$ \\
\hline Grand Total & 64 & 134518 & 90 & $6,386.62$ \\
\hline
\end{tabular}

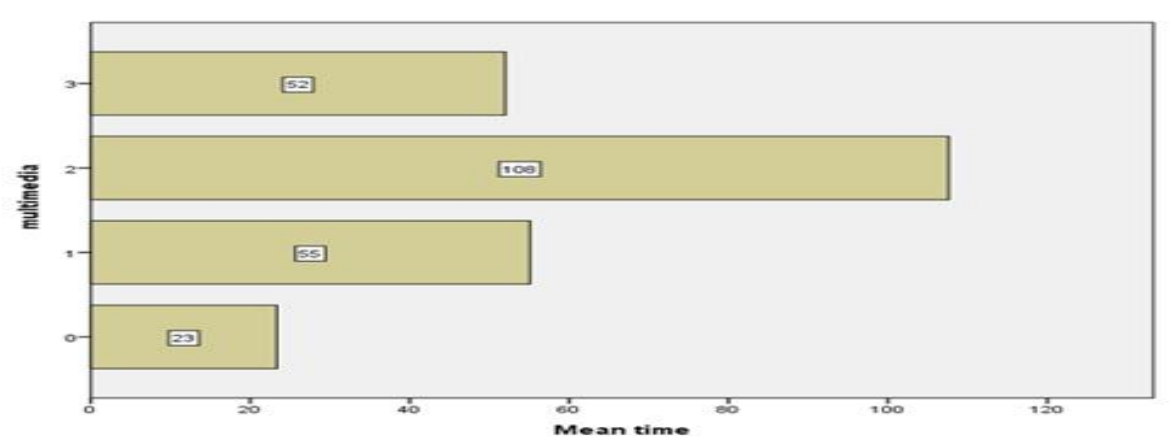

FIGURE 3 . Average development time vs. levels of multimedia

Question 17:

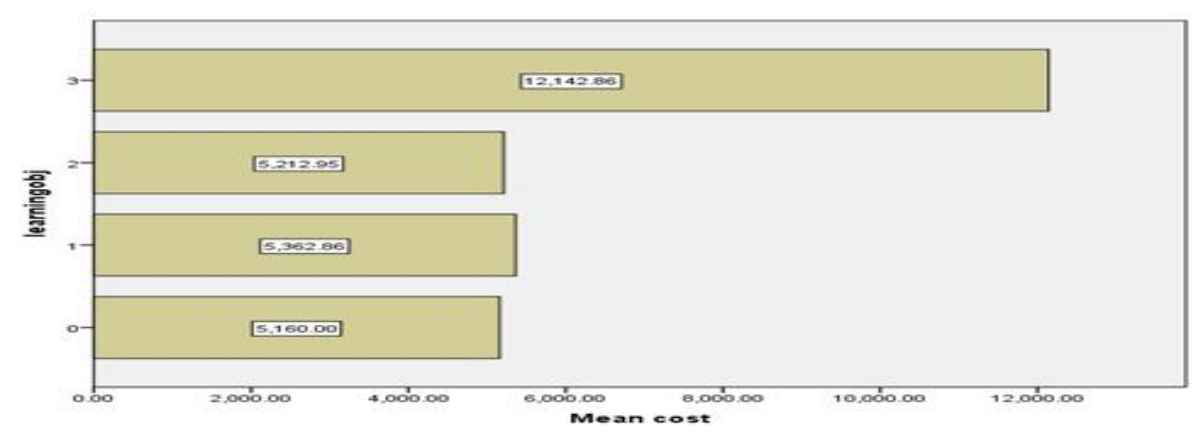

FIGURE 4 . Development cost vs. learning objective 
TABLE 6. Results of data by level of multimedia used; Question 15

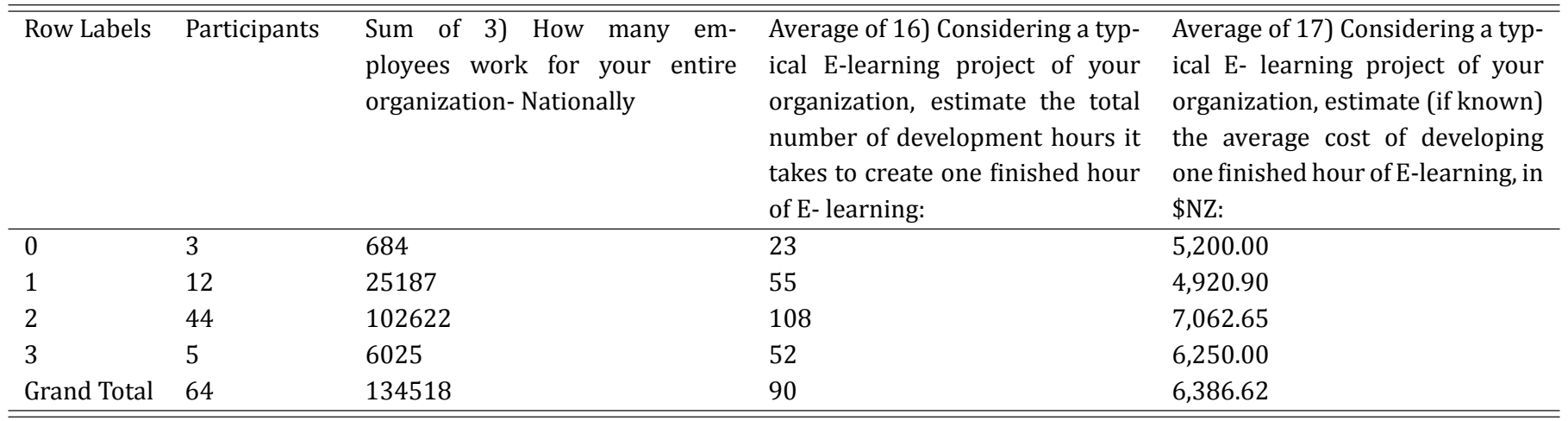

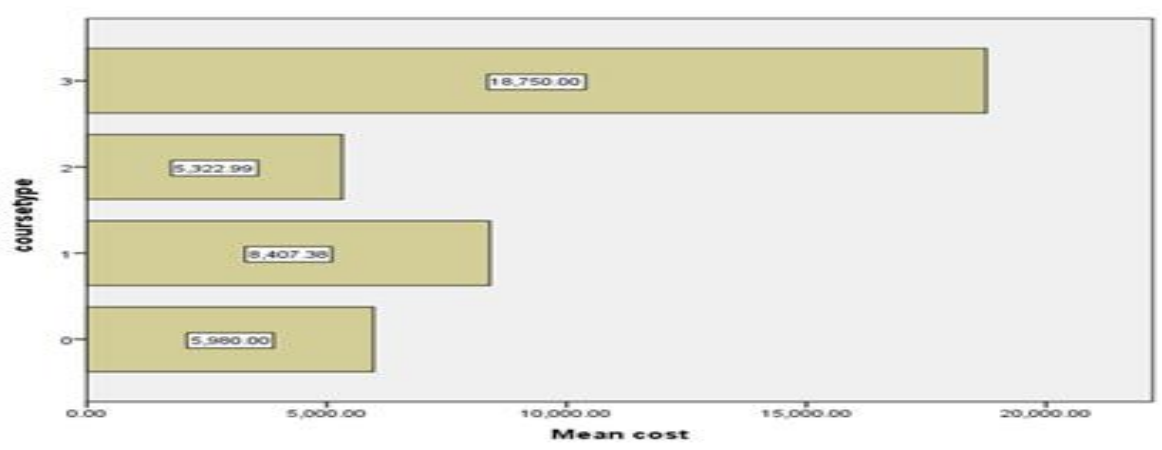

FIGURE 5 . Development cost vs. course type

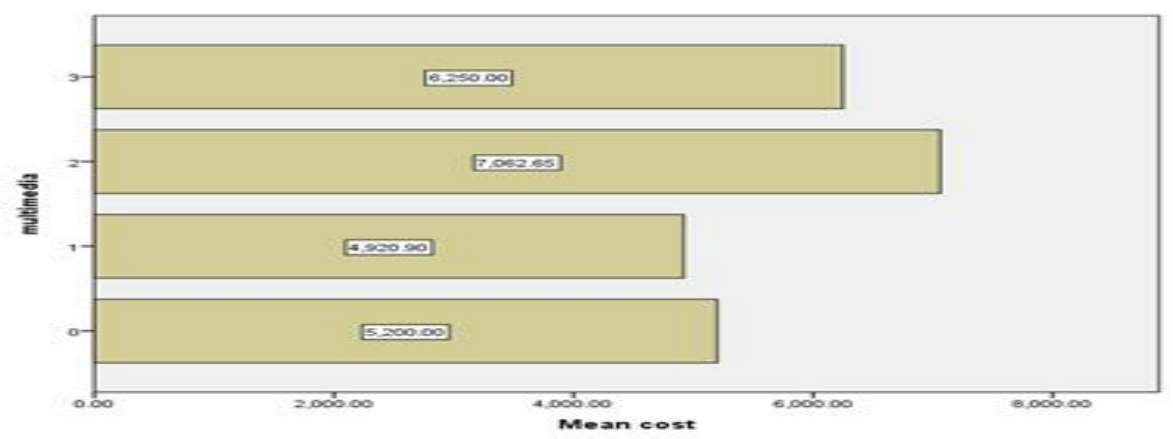

FIGURE 6 . Development cost vs. multimedia

\section{DISCUSSION}

A limitless number of variables and factors that come into play when attempting to accurately rate the development cost of your E-learning course, it's no wonder this subject is constantly revisited time and time again. Kapp and Robyn (2009) are true to conclude that designing training is as much of an art as it is a science. While declaring the findings, the researchers have noted an important fact that the respondents only provided numbers as data to the survey items that they have used or applied to them. The researchers have unveiled some interesting results from the survey as mentioned below:

This survey represented approximately 134518 employees all over NZ in various jobs related to E-learning development roles in different industries of NZ. The dominant message from the results indicates four findings. It is significant in NZ E-learning development industry that one employee within the company may be job sharing inter-related roles. Or 
in other words as company ID 153 mentions, 'one person wears many hats'. See company reference ID 66, 108 and 112 and 153 of question 7 and its comments section mentions that an employee may be the technical writer and instructional developer simultaneously, or a manager and instructional developer duties both shared by the same person within the company indicating the need for employers to employ experts by job specification for optimum profit.

The statistics indicated in answers to questions two and three that nearly half i.e., 56.25 percent ( 36 out of 64 ) respondents in NZ E-learning industry were also a part of a Global company indicating that NZ E-learning industry has a major role to play in the Global learning development world. It is noteworthy that E-learning solutions developed by the 64 New Zealand industries were used by a range of approximately 164000 to 169000 users or learners including employees, partners, external customers, etc. in NZ and abroad as reported by question eight of the survey item and its comments.

The research statistics indicated that a majority of the employees in the E-learning industry in NZ worked full time jobs 40 hour/week as indicated by question two. It is interesting to know that approximately a third ( 25 of 64 ) of the respondent companies outsourced their work. The outsourcing may point to the lack of labor within NZ and also less financial liability. It is indicative of a need of more instructional developer roles to be invited in NZ to reduce the need of outsourcing. It is noteworthy from the statistics of question six that 96.88 percent (62 out of 64 ) of the internal staff employed in the Elearning industry in $\mathrm{NZ}$ were directly related to the E-learning design and development specifying the efficiency of the Human resourcing team in NZ E-learning development to employ qualified people for the jobs.

\section{CONCLUSION}

The study findings presented in this research estimated that the average time to develop one hour of E-learning in NZ was approximately 90 hours. The cost to develop one hour of E-learning was approximately 6300 NZD. An important finding was that the maximum number of E-learning development companies in NZ developed instruction satisfying application of learned skills as learning objective, interactive scenarios course type and intermediate level multimedia was used. The results of the survey suggest that there are various factors that affect the time and costs of E-learning development as discussed in the literature hence, the cost may not be in direct proportion with the level of E-learning created. The cost and time analysis of any proposed E-learning project will enhance the profits in terms of tangible and intangible benefits for the company. But one must keep in mind that the behavior of costs as output also varies on how output is defined and measured (Morris, 1995). Whilst asserting that the relationship between research and practice is complex, the researchers found that time-tracking and good project management skills along with regular ROI calculations can make a significant contribution to time and cost reduction in development. It is unrealistic to expect that only the answer, 'it depends' suffices for the research question, "What are the E-learning development time and costs in New Zealand organizations?" to apply the findings of research in practice. When it comes to developing E-learning courses, the requirements that are related to budget vary all the time. We agree with Butterfield (2002) in saying that the overall aim is to maximize the benefits for employees and the businesses by making cost-effective decisions for the implementation of E- learning in New Zealand. 


\section{LIMITATIONS AND RECOMMENDATIONS}

Since, E-learning development industry is booming in NZ, thus this field has lot more potential to be expanded and explored. This study covered a small portion of this domain and call researchers to investigate it further. As per the findings, the areas of development would be to develop much advanced level of E-learning including simulations and games, course type to teach analysis and synthesis of skills using much advanced multimedia. Elearning is not just a carrier for cutting costs and diminishing the learning options but, the needs of the learners and the business must take priority and shape our thinking as we consider the investment options for using technology to create a quality learning experience.

\section{REFERENCES}

Bachmann, Duane, John Elfrink, and Gary Vazzana. 1996. Tracking the progress of e-mail vs. snail-mail. Marketing Research 8: 31-35.

Bartley, Sharon J., and Jennifer H. Golek. 2004. Evaluating the cost effectiveness of online and face-to-face instruction.

Jour- nal of Educational Technology \& Society 7, no. 4: 167-175.

Bates, AW. 2000. Managing technological change: Strategies for college and university leaders. San Francisco, CA: Jossey-Bass Publishers.

Butterfield, Shona. 2002. Highways and pathways: Exploring New Zealand's E-learning opportunities. URL: goo.gl/JcgSG6 (accessed 15 December, 2015).

Chapman, Bryan. 2010. How long does it take to create learning? URL: goo.gl/p3IZnP (accessed September 11, 2015).

Crump, Barbara, and Andrea McIlroy. 2003. The digital divide: Why the" don't-want-tos" won't compute: Lessons from a New Zealand ICT project. First Monday 8, no. 12. DOI: 10.5210/fm.v8i12.1106

Dabner, Nicki, Sonja Bailey, Jilaine Johnson, and Niki Davis. 2010. Proceedings of Ulearn 10. URL: goo.gl/V11mkR (ac cessed September 10, 2016).

Daniel, John W. 1996. Mega-universities and knowledge media: Technology strategies for higher education. London, UK: Kogan Page Limited.

Dillman, Don A. 2000. Mail and internet surveys: The tailored design method. New York, NY: Wiley.

Dillman, Don A. 1998. Mail and other self-administered surveys in the 21st Century: The beginning of a new era. URL: goo.gl/xkgRSv (accessed November 14, 2016).

Dillman, Don A. 2002. Presidential address: Navigating the rapids of change: Some observations on survey methodology in the early twenty-first century. The Public Opinion Quarterly 66, no. 3: 473-494. DOI: 10.1086/342184

Dillman, Don. A., Robert D. Tortora, and Dennis Bowker. 1999. Principles for constructing web surveys. URL: goo.gl/BUL-

fUc (accessed November 14, 2016).

Fowler, Floyd J. 2002. Survey research methods. 3rd ed. Thousand Oaks, CA: Sage Publications.

Garg, Amit. 2010. 'A fresh look at levels of custom e-learning solutions. URL: goo.gl/dgTXnT (accessed November 14, 2016).

Grover, Varun. 2003. A tutorial on survey research: From constructs to theory. URL: goo.gl/7JLCUY (accessed October 15, 2015).

Gulati, Shalni. 2008. Technology-enhanced learning in developing nations: A review. The International Review of Research in Open and Distributed Learning 9, no. 1: 1-16. D0I: 10.19173/irrodl.v9i1.477

Higgins, AH, and Prebble T. 2008. Taking the lead: Strategic management for E-learning. Wellington, NZ: An Ako Aotearoa Publication.

Kapp, Karl M., and Robyn A. Defelice. 2009. Time to develop one hour of training. URL: goo.gl/5pwXRD (accessed November 14, 2016).

Katz, Richard N. 1999. Competitive strategies for higher education in the information age. Educom Review 34: 38-41.

Litwin, Mark S. 1995. How to measure survey reliability and validity. Vol. 7. Thousand Oaks, CA: Sage Publications. DOI: $10.4135 / 9781483348957$ 
Mehta, Raj, and Eugene Sivadas. 1995. Comparing responses rates and response content in mail versus electronic mail sur- $\quad$ veys. Journal of the Market Research Society 37, no. 4: 429-440.

Morris, Stephen. 1995. The common prior assumption in economic theory. Economics and Philosophy 11, no. 2: 227-253. DOI: $10.1017 / \mathrm{S} 0266267100003382$

New Zealand Ministry of Economic Development. 2001. Observations for APEC work agenda on narrowing the digital divide. URL: goo.gl/BbZofO(accessed September 11, 2015).

Nuchso, Narumit, Sudarat Tuntivivat, Piyapong Klayklueng. 2016. The effect of learning organization and servant leadership on child-centered teaching behavior with the mediating role of knowledge sharing in education of Chanthaburi Diocese schools. International Journal of Humanities, Arts and Social Sciences 2, no. 5: 181-188.

DOI: 10.20469 /ijhss.2.20004-5

$\mathrm{Si}$, Li, and Wanigasooriya Priyanwada . 2016. An investigation and analysis of online public access catalogues (OPACs) in university libraries in Sri Lanka. International Journal of Humanities, Arts and Social Sciences 2, no. 1: 28-39.

DOI: 10.20469 /ijhss.2.20003-1

Siegel, Kevin. 2016. Adobe captivate, TechSmith Camtasia Studio, articulate storyline: Production times.

URL: goo.gl/RIYlsr (accessed November 14, 2016).

Tarmuchi, Nor R., Haslinda Mohamed, and Saidatul Akmar I. 2015. Asynchronous learning tools use in graduate study: A preliminary survey. International Journal of Humanities, Arts and Social Sciences 1, no. 1: 13-18.

DOI: 10.20469 /ijhss.20003

Tucker, Christy. 2014. Time estimates for e-learning development. URL: goo.gl/gZYl8P (accessed November 14, 2016).

— This article does not have any appendix. - 